Institute of Physics on May 15, taking as his subject "Physics and Science Museums". Sir Henry referred in particular to the work which the Board of the Institute has done through a special committee in locating pieces of physical apparatus of special historical importance, and ensuring so far as possible that they should be preserved from deterioration or possible loss. This committee was appointed in 1925 , and since then it has brought to light many objects which were little known to physicists generally and of which the historical importance was not always appreciated at its full value. It was not until the middle of the eighteenth century that the first institution was established for the preservation of scientific instruments and technical apparatus; this was the museum of the Conservatoire des Arts et Metiers in Paris, which was founded in 1794 to include all kinds of machinery, models, tools, instruments, etc. Little can now remain of the instruments and apparatus in use in earlier times, not only because in those times there was no institution where they could be deposited, but also because for the most part their historical importance was seldom realised. Then probably more than now, an instrument once acquired was treasured for there were few of them, but it passed in time to a later generation which neither appreciated it nor understood its importance. The same influence operates to-day and there is much difficulty in securing for posterity the more important examples of apparatus which has played a part in the advance of science. The address will be published in due course and copies will be obtainable from the Institute of Physics, 1, Lowther Gardens, Exhibition Road, London, S.W.7 (1s. 1 d. including postage).

\section{A New Nature Reserve in New Zealand}

THe property of Brooklands, New Plymouth, New Zealand, was handed over by the trustees of the late Mr. Newton King to the Borough of New Plymouth as a public reserve and officially opened by His Excellency the Governor-General, Lord Bledisloe, on March 10. It adjoins the beautiful Pukekara Park, and forms a natural extension of it. Together they comprise an area of more than 100 acres, forming a park second to none in the Dominion either in size or natural beauty. In addition to the actual property of Brooklands, the Trustees presented five acres of native bush nearby, and, to give access to it and make the whole one large reserve, Mr. T. C. List and Mr. C. A. Wilkinson gave an area of seven and a half acres. In his speech, Lord Bledisloe, after paying tribute to the late Mr. King, pointed out some of the many natural advantages which the Dominion possesses, and said that it is unique in the number, variety and grandeur of its many beauty spots within a relatively small area and in its incomparable native bush; he prophesied that eventually New Zealand will find its tourist traffic the main source of its wealth. While admiring the fine specimens of introduced trees, Lord Bledisloe gave a word of warming against the mixing of exotic trees with the native vegetation. All those who have the preservation of the native vegetation of the Empire at heart will feel grateful for the interest which Lord Bledisloe has in their efforts, and for the help he is giving them.

\section{Safety in X-ray work}

IN a paper to the Institution of Electrical Engineers read on February 22, by Mr. L. G. H. Sarsfield, safety measures for workers with $\mathrm{X}$-ray plant were discussed. He discussed the risks of fatal injury and the advantages and disadvantages of using signal lights. The concluding portion of the paper dealt with the use of high voltage flexible cable and described some new types of cable which are coming into use. Stress was laid on the need for definite instructions so as to avoid electrical dangers. $\mathrm{He}$ suggested that the Institution should co-operate with the British Institute of Radiology in framing rules. In the discussion, Dr. V. E. Pullin said that at Woolwich they had to legislate for uninstructed use, and so had to make the equipment absolutely safe. Dr. G. W. C. Kaye, speaking as secretary of the International Protection Committee which will meet at Zurich next July, pointed out that international recommendations were framed as the result of the British Protection Committee's work, and these recommendations play a very important part in the design of equipment all over the world. The League of Nations has issued a very comprehensive publication on the subject. The British recommendations are now being revised and he hopes that the use of rubber floor mats and insulating shoes will have more consideration. Dr. B. J. Leggett said that too much talk of the need of protection made patients nervous. In some cases, too much protection will prevent results being obtained. In reply, Mr. Sarsfield said that there is a real need for earthing the conductor at intervals along its length.

\section{Rothamsted Experimental Station}

THE appeal for funds to purchase the Rothamsted fields has now secured in cash or good promises the $£ 10,000$ necessary to claim the munificent donations of $£ 15,000$ by Mr. Robert McDougall and $£ 5,000$ by the Sir Halley Stewart Trust (see Nature, 133, 442, March 24, 1934). The success of the purchase scheme is therefore assured, and the appeal is being kept open only a few days longer in order to enable the Committee to obtain the further amount needed to meet the agreed addition to the purchase price consequent on the ascertainment of the tithe charges, timber evaluation and other items. Several organisations still have to make their final decisions, but it is confidently expected that the whole amount including these additional payments will be secured within the next few days, so that the Rothamsted Committee can enter into possession free of all financial obligation and free therefore to devote the whole of its resources to the important agricultural investigations in hand.

\section{Annual Meeting of the British Medical Association}

THE one hundred and second annual meeting of the British Medical Association will be held in Bournemouth during the week commencing July 23 
under the presidency of Dr. S. Watson Smith, and an interesting account by Mr. Bernard Calkin of some of the geological and archæological features in the neighbourhood of Bournemouth is given in the British Medical Journal of May 5, p. 814. Palæolithic implements, bronze and early iron age relics, and Roman remains have been found in several localities. Eight of the seventeen known Hampshire earthenware 'beakers' of the 'Beaker Folk' (circa 1700 B.c.) were found at Bournemouth. Early Iron Age sites in Bournemouth generally yield little beyond pottery fragments, whereas in similar sites around Swanage, animal bones and bone implements are frequent, being preserved in the limestone district there, but perishing in the sand and gravel of Bournemouth.

\section{Announcements}

Prof. W. J. DAkin, Challis professor of zoology in the University of Sydney, has been elected president of the Linnean Society of New South Wales.

Lieut.-Col. S. P. James, of the Ministry of Health, has been awarded the Darling Memorial Medal and Prize of the Health Committee of the League of Nations for his work on malaria therapy.

The Abbé Henri Breuil has accepted the presidency of the Prehistoric Society of East Anglia for 1934 and will give an address at the meeting of the Society at the rooms of the Society of Antiquaries, Burlington House, London, on May 23 at 2.30 on "Engraved and Sculptural Stone Monuments in the British Isles of the Transition Period between the Stone and Bronze Ages: an Essay of Chronology and Interpretation". Non-members of the Society wishing to be present should apply to the honorary secretary, Mr. G. Maynard, The Museum, Ipswich.

THe following awards have been made by the Royal Aeronautical Society : Simms Gold Medal to Sir Gilbert Walker, for his paper on cloud formation ; Taylor Gold Medal to Mr. A. Plesman (managing director of K.L.M.), for his paper on the AmsterdamBatavia service; Wakefield Gold Medal to Senor J. de la Cierva, for his work on the development of the autogiro; Busk Memorial Prize to Mr. A. V. Stephens, for his paper on recent research in spinning; Pilcher Memorial Prize to Mr. W. H. Lewis, for his paper on duralumin in aircraft construction.

The Council of the Institution of Electrical. Engineers has made the following awards of premiums for papers read during the session 1933-34, or accepted for publication: Institution premium to W. Kidd and J. L. Carr ; Ayrton premium to B. A. G. Churcher, A. J. King, and H. Davies; Fahie premium to T. S. Skillman; John Hopkinson premium to Dr. W. G. Thompson; Kelvin premium to B. L. Goodlet; Paris premium to Dr. J. L. Miller, and J. E. L. Robinson; Webber premium to G. Shearing ; Overseas premium to S. P. Chakravarti; extra premiums to Dr. M. A. B. Brazier, Capt. B. S. Cohen, C. W. Marshall, P. D. Morgan, W. G. Radley and Dr. S. Whitehead, H. Rissik. Wireless Section
Premiums : Duddell premium to T. Walmsley; Extra premiums to L. H. Bedford and O. S. Puckle; E. B. Moullin, and H. D. M. Ellis ; A. H. Reeves. Meter and Instrument Section Premiums : Silvanus Thompson premium to Dr. A. H. M. Arnold; extra premiums to J. B. Lees, Dr. E. Mallett, G. F. Shotter. Willans Premium, for a paper dealing with the utilisation or transformation of energy : Mr. D. B. Hoseason for his paper on :-_"The Cooling of Electrical Machines".

Prof. G. Ellurot Smrth writes: "Acting on the advice of my physicians, I have been persuaded that it is essential on grounds of health to resign the position of president of the recently established International Institute of Psychical Research. I deeply regret the necessity for this action at the present moment, when the Institute is about to embark upon certain interesting experiments the results of which should afford ample justification for its existence."

THE Royal Society of Edinburgh commemorated the completion of its hundred and fiftieth year at a meeting of the Society held on May 7, 1934, with Sir E. A. Sharpey-Schafer, president, in the chair. Prof. D'Arey W. Thompson delivered an address entitled "Fifty Years Ago". In the evening the Lord Provost, Magistrates and Council of the City of Edinburgh gave a civic reception to the fellows in the Galleries of the Royal Scottish Academy, which, as the "Royal Institution", was for more than eighty years the home of the Society.

Applications are invited for the following appointments, on or before the dates mentioned :-A University demonstrator in physical chemistry at the University of Cambridge-Mr. H. Thirkill, Clare College (May 24). A lecturer in biology at the Diocesan Training College, Fishponds, BristolThe Principal (May 26). A chief assistant engineer to the Rivers Mersey and Irwell Catchment Board-The Clerk to the Board, County Offices, Preston (May 26). A psychologist at the North West District Child Guidance Clinic-The Secretary, 18, Belsize Crescent, London, N.W.3 (May 30). Junior technical assistants (mechanical engineers and chemists) in the Supply Board Technical Establishment, under the Director of Ordnance Factories-The Under-Secretary of State (C.5), The War Office, London, S.W.1 (May 30). A lecturer in geology at the Wigan and District Mining and Technical College-The Principal (May 31). A head of the Civil and Mechanical Engineer. ing Department, and a lecturer in electrical engineering at the Northampton Polytechnic Institute, St. John Street, London, E.C.I-The Principal (May 31). A principal of the Municipal Technical College, Bolton-The Director of Education, Education Offices, Nelson Square, Bolton (May 31). A lecturer in geography and a lecturer in mathematics at Lincoln Training College-The Principal. An assistant lecturer in zoology, and a lecturer in economics, at the University College of North Wales, Bangor-The Registrar (June 2). 